\title{
FACTORS INFLUENCING RELATIVE RATES OF SYNTHESIS OF ADULT AND FETAL HEMOGLOBIN IN VITRO*
}

\author{
By DAVID W. ALLEN † AND JAMES H. JANDL \\ (From the Thorndike Memorial Laboratory and Second and Fourth (Harvard) Medical \\ Services, Boston City Hospital, and the Department of Medicine, Harvard \\ Medical School, Boston, Mass.)
}

(Submitted for publication January 7, 1960; accepted March 3, 1960)

What causes the gradual decrease of fetal hemoglobin in the normal maturing infant, or the persistence of fetal hemoglobin in the blood of adults with certain congenital anemias, especially thalassemia, is not known. The production of fetal hemoglobin is evidently determined by genes nonallelic with those regulating adult hemoglobin formation (1). The fact that all red cells can be sickled in sickle cell anemia patients having relatively high proportions of fetal hemoglobin indicates that the same cell can produce both an adult hemoglobin (i.e., S) and fetal hemoglobin. This in turn implies that the rate of formation of fetal hemoglobin is not dependent upon the formation of a different cell by a different gene, but reflects a metabolic adaptation by the individual young red cells of the fetus or of the abnormal adult to the cellular environment (2).

The present investigation concerns the effect of cellular environment on the relative quantities of fetal and adult hemoglobin synthesized in vitro by the reticulocytes of umbilical cord blood, as determined by the rates of $\mathrm{Fe}^{59}$ incorporation into heme and of $\mathrm{C}^{14}$-leucine incorporation into globin.

\section{MATERIALS AND METHODS}

$\mathrm{Fe}^{39}$ was obtained from Abbott Laboratories, and ironbinding protein of high degree of purity was a gift from Dr. John K. Inman (3). To aqueous solutions of the protein, buffered with $20 \mathrm{mM}$ sodium bicarbonate so as to yield a final $\mathrm{pH}$ of $7.4 \pm 0.2$, sufficient iron either as $\mathrm{Fe}^{59} \mathrm{Cl}_{3}$ or $\mathrm{Fe}^{56} \mathrm{Cl}_{3}$, was added dropwise to one-third saturate the iron-binding protein. To insure complete protein-binding of the added iron, the mixture was allowed to stand at room temperature for 1 hour prior to its experimental use.

Leucine uniformly labeled with $\mathrm{C}^{14}$ was purchased from Nuclear of Chicago and had a specific activity of $43 \mu \mathrm{c}$

* This investigation was supported in part by Research Grant RG3507 (C7) from the National Institutes of Health, Bethesda, Md.

$\dagger$ Research Fellow, Public Health Service. per mg. Nonradioactive amino acids were obtained from Schwarz Bioresearch Laboratories. IRC-50 resin was supplied by Rohm and Haas Company and purified and equilibrated as previously described (4).

Incubation. From 30 to $50 \mathrm{ml}$ of sterile heparinized umbilical cord blood was obtained at the time of delivery. It was centrifuged at $2,000 \mathrm{G}$ for 30 minutes at $0^{\circ} \mathrm{C}$ and the top $5 \mathrm{ml}$ of red cells, relatively rich in reticulocytes, was withdrawn and washed twice with Krebs-Ringer phosphate with glucose solution, $\mathrm{pH} 7.4$, at $0^{\circ} \mathrm{C}$. In the studies of glucose deficiency, glucose was omitted. An approximately 50 per cent suspension of the washed red cells was made with the same solution and a hematocrit value and reticulocyte count obtained. Two $\mathrm{ml}$ aliquots of this red cell suspension were then pipetted into $25 \mathrm{ml}$ siliconized Erlenmeyer flasks. To this was added $1 \mathrm{ml}$ of the amino acid mixtures in Krebs-Ringer phosphate with glucose solution so that their final concentration was twice that of normal fasting levels, as determined by Stein and Moore (5), with the exception of glycine which was made up to 4 times its normal value. In certain experiments valine, isoleucine and histidine were omitted. In other experiments, in which $\mathrm{C}^{14}$ leucine was used as a tracer, the radioactive amino acid was substituted for the stable form.

The red cell suspension was preincubated in a Dubnoff metabolic incubator at $37^{\circ} \mathrm{C}$ with shaking at approximately 20 times per minute. In experiments on the effects of hypoxia this was done in separate tents under water-saturated gas mixtures containing 95 per cent $\mathrm{O}_{2}$ and 5 per cent $\mathrm{CO}_{2}$ or 95 per cent $\mathrm{N}$ and 5 per cent $\mathrm{CO}_{2}$ at a flow rate of $1 \mathrm{~L}$ per minute. In other experiments the samples were incubated under water-saturated room air. After 1 hour, there was added sufficient $\mathrm{Fe}^{50}$-labeled iron-binding protein to yield a final concentration of 24 $\mu \mathrm{M}$ and sufficient $\mathrm{C}^{12}$-leucine to yield a final concentration of $2.6 \mathrm{mg}$ per $100 \mathrm{ml}$. To alternate flasks equal amounts of $\mathrm{Fe}^{56}$-containing iron-binding protein and $\mathrm{C}^{14}$-leucine were added. The flasks were then incubated 4 hours longer.

Separation of hemoglobins. The period of incubation was terminated by the addition of 10 volumes of 0.85 per cent $\mathrm{NaCl}$ at $0^{\circ} \mathrm{C}(6)$ and the red cells were washed 5 times in 0.85 per cent $\mathrm{NaCl}$ at $0^{\circ} \mathrm{C}$, suspended in $1 \mathrm{ml}$ of 0.85 per cent $\mathrm{NaCl}$ and dialyzed overnight against 250 $\mathrm{ml}$ of distilled water. The resulting hemolysate was removed from the dialysis sack, $0.8 \mathrm{ml}$ of toluene was added, the solution was shaken vigorously for 5 minutes, after 
which $0.4 \mathrm{ml}$ of 5 per cent $\mathrm{NaCl}$ was added. The solution was then centrifuged at $2,000 \mathrm{G}$ for 30 minutes or until the middle hemoglobin-containing layer was clear. The hemoglobin was removed by pipetting and dialyzed for 24 hours against a phosphate buffer, $0.06 \mathrm{M}$ in sodium ions, $0.01 \mathrm{M}$ in cyanide ions, $\mathrm{pH} 6.91 \pm 0.02[\mathrm{De}-$ veloper no. 4 (4)]. After removal from the dialysis sack, the hemoglobin solutions were found to have a concentration of $70 \pm 10 \mathrm{mg}$ per $\mathrm{ml}$. One $\mathrm{ml}$ of each sample was then pipetted on a $0.9 \times 35 \mathrm{~cm}$ column of IRC-50 resin, previously equilibrated against Developer no. 4 and the sample was washed into the column with $0.2 \mathrm{ml}$ samples of developer. The columns were then developed for 5 to 7 hours at $4^{\circ} \mathrm{C}$ with Developer no. 4 flowing at a rate of 5 to $7 \mathrm{ml}$ per hour (4). By then the main component of adult hemoglobin was 1 to $5 \mathrm{~cm}$ from the top of the column, and $F_{I I}$, the main component of fetal hemoglobin (4), was approximately 12 to $30 \mathrm{~cm}$ from the top of the column. The resin was removed by extrusion and the individual bands were dissected out and eluted from the resin with $3 \mathrm{ml}$ of saturated disodium phosphate at room temperature. The $\mathrm{pH}$ of this eluted hemoglobin solution was 7. The hemoglobin concentration in each band was determined at $540 \mathrm{~m} \mu$ on a Coleman Junior spectrophotometer. The fetal hemoglobin concentration obtained from the $F_{I I}$ band is expressed as the percentage of the total eluted hemoglobin. Since this main component of $\mathrm{F}$ hemoglobin includes about 80 per cent of the total fetal hemoglobin (4), the values will be approximately 20 per cent lower than one might expect from alkali denaturation.

Determination of radioactivity. Hemoglobin labeled with $\mathrm{Fe}^{59}$ was counted in a well-type scintillation counter. In four experiments, after addition of known amounts of nonradioactive hemoglobin as carrier, the heme was also separated from the globin and crystallized to constant specific activity after the method of Shemin (7). In all instances the value of the activity per milligram of hematin chloride corresponded to that of hemoglobin, assuming heme to constitute 3.9 per cent of hemoglobin. Thus the activity is reported in terms of hemoglobin for ease in comparison with $\mathrm{C}^{14}$-leucine labeling of globin.

In experiments in which $\mathrm{C}^{\mathbf{1 4}}$-leucine was used, the hemoglobin, after elution from the column, was dialyzed against $0.001 \mathrm{M} \mathrm{NaCN}$, the concentration of the hemoglobin was determined, and $0.1 \mathrm{ml}$ samples were pipetted on stainless steel planchets. These samples were then counted with a windowless flow counter, and corrected to a sample size of $0.5 \mathrm{mg}$ using an empirical self-absorption curve. Experiments on large samples demonstrated that all the radioactivity of $\mathrm{C}^{\mathbf{1 4}}$-leucine-labeled hemoglobin, after it had been chromatographically purified, was in the globin fraction and was precipitable by 5 per cent trichloroacetic acid.

\section{RESULTS}

Effect of hypoxia. Table I shows the results of six experiments done to investigate the effects of hypoxia on the relative amounts of adult hemoglobin and of fetal hemoglobin synthesized. Since the ratio of fetal/adult hemoglobin is variable from one cord blood sample to another, only comparison with the control ratio is informative. In the last column is given the percentage change in the ratio produced by hypoxia. In every case there

TABLE I

Effect of hypoxia on the relative rates of synthesis of adult and fetal hemoglobin by cord blood reticulocytes in vitro

\begin{tabular}{|c|c|c|c|c|c|c|c|c|c|}
\hline \multirow[b]{2}{*}{ Label } & \multirow[b]{2}{*}{$\begin{array}{l}\text { Reticulo- } \\
\text { cytes }\end{array}$} & \multirow[b]{2}{*}{$\mathrm{F}_{I 1} *$} & \multicolumn{3}{|c|}{$95 \% \mathrm{O}_{2}$} & \multicolumn{3}{|c|}{$95 \% \mathrm{~N}_{2}$} & \multirow{2}{*}{$\begin{array}{c}\text { Per cent increase } \\
\text { Ratio } \\
\mathrm{FN}_{2} / \mathrm{AN}_{2} \\
\frac{-\mathrm{FO}_{2} / \mathrm{AO}_{2}}{\mathrm{FO}_{2} / \mathrm{AO}_{2}}\end{array}$} \\
\hline & & & $\mathrm{FO}_{2}$ & $\mathrm{AO}_{2}$ & $\begin{array}{c}\text { Ratio } \\
\mathrm{FO}_{2} / \mathrm{AO}_{2}\end{array}$ & $\mathrm{FN}_{2}$ & $\mathrm{AN}_{2}$ & $\begin{array}{c}\text { Ratio } \\
\mathrm{FN}_{2} / \mathrm{AN}_{2}\end{array}$ & \\
\hline & $\%$ & $\%$ & \multicolumn{2}{|c|}{$c p m \prime^{\prime} m g H b$} & \multicolumn{4}{|c|}{$c p m / m g H b$} & \\
\hline $\mathrm{Fe}^{59}$ & 4.9 & 57 & 25 & 120 & 0.208 & 27 & 97 & 0.278 & 34 \\
\hline $\mathrm{Fe}^{59}$ & 1.1 & 60 & 70 & 201 & 0.348 & 130 & 315 & 0.413 & 19 \\
\hline $\mathrm{Fe}^{59}$ & 6.7 & 75 & 43 & 123 & 0.350 & 111 & 168 & 0.661 & 89 \\
\hline & & & 35 & 87 & 0.402 & 66 & 113 & 0.584 & 45 \\
\hline $\mathrm{Fe}^{59}$ & 15.2 & 50 & 1,129 & 2,270 & 0.497 & 613 & 1,034 & 0.593 & 19 \\
\hline & & & 1,117 & 2,311 & 0.483 & 633 & 1,004 & 0.630 & 30 \\
\hline \multicolumn{10}{|c|}{ As hemet: } \\
\hline \multirow{2}{*}{\multicolumn{2}{|c|}{$\begin{array}{l}\text { 2nd crystallization } \\
\text { 3rd crystallization }\end{array}$}} & & 1,424 & 2,668 & 0.534 & 763 & 1,180 & 0.647 & 21 \\
\hline & & & 1,586 & 2,947 & 0.538 & 858 & 1,228 & 0.699 & 30 \\
\hline $\mathrm{Fe}^{59}$ & 8.0 & 59 & 1,094 & 2,208 & 0.495 & 671 & 1,142 & 0.588 & 19 \\
\hline \multicolumn{2}{|c|}{$\mathrm{C}^{14}$-leucine } & & 1,396 & 2,630 & 0.531 & 1,048 & 1,785 & 0.587 & 11 \\
\hline $\mathrm{Fe}^{59}$ & 6.0 & 68 & 408 & 866 & 0.471 & 863 & 1,520 & 0.568 & 21 \\
\hline $\mathrm{C}^{14}-\mathrm{le}$ & cine & & 883 & 1,728 & 0.511 & 1,172 & 2,168 & 0.541 & 6 \\
\hline
\end{tabular}

* Main component of fetal hemoglobin determined by chromatography.

$\dagger$ Counted as crystallized heme, but specific activity calculated as hemoglobin. 


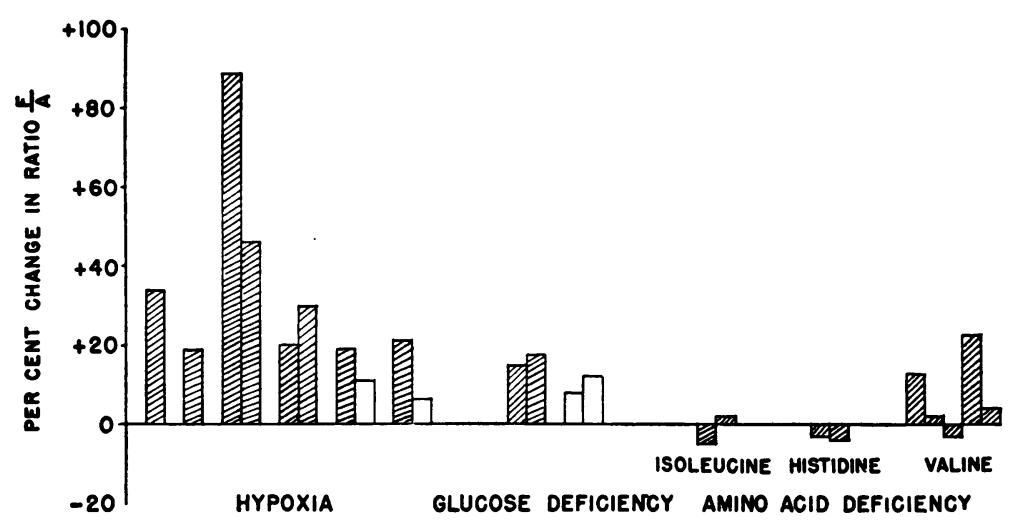

FIG. 1. EFFECT OF VARIOUS DEFICIENCIES ON THE RELATIVE SYNTHESIS OF FETAL AND ADULT HEMOGLOBIN BY UMBILICAL CORD RETICULOCYTES IN VITRO. The percentage change in the ratio $\frac{\text { fetal hemoglobin synthesized }}{\text { adult hemoglobin synthesized }}$ as compared to a nondeficient control is shown. Bar graphs for experiments in which $\mathrm{Fe}^{59}$ was used as a label are shaded, while those for $\mathrm{C}^{14}$-leucine experiments are unshaded.

was a rise in the ratio of radioactive fetal/adult hemoglobin, indicating that hypoxia produced a relative stimulation of synthesis of fetal hemoglobin compared to adult hemoglobin. A chisquare test of the ten incubations done here shows significance at the 0.5 per cent level. Figure 1 summarizes the effects of hypoxia, as well as other factors, on relative fetal hemoglobin production.

Although hypoxia uniformly stimulated fetal hemoglobin synthesis relative to adult hemoglobin synthesis, Table I demonstrates a variable effect of oxygen deprivation on the specific activity of hemoglobin ( $\mathrm{A}$ and $\mathrm{F}$ combined). Red blood cells represent a peculiarly difficult tissue in which to obtain complete anoxia because of the large reservoir of oxygen in the hemoglobin. It was supposed that the variable effect of hypoxia on the specific activity might be a result of different degrees of oxygen deprivation achieved, since there is evidence that with complete anoxia no hemoglobin synthesis would occur (8). Hence, in two similar experiments, one of which is illustrated in Figure 2, we departed from the usual protocol. The Erlenmeyer flasks were stoppered with airtight vaccine caps and preincubated for 1.5 hours with the following gas mixtures: 95 per cent $\mathrm{O}_{2}$ and 5 per cent $\mathrm{CO}_{2} ; 13$ per cent $\mathrm{O}_{2}, 82$ per cent $\mathrm{N}_{2}$ and 5 per cent $\mathrm{CO}_{2}$; and 95 per cent $\mathrm{N}_{2}$ and 5 per cent $\mathrm{CO}_{2}$. In one flask incubated with 95 per cent $\mathrm{N}_{2}$ and 5 per cent $\mathrm{CO}_{2}$, a well containing $0.5 \mathrm{ml}$ of 35 per cent hydrosulfite was employed to further decrease the oxygen tension. The $\mathrm{Fe}^{59}$-iron-binding protein was then added under nitrogen, and the sealed flasks incubated for 5.5 hours longer. The percentage saturation of each hemoglobin sample was then determined by the method of Gordy and Drabkin (9). The treatment of the samples and the crystallization of the heme to constant specific activity were then carried out as usual. It can be seen from Figure 2 that mild hypoxia tended to increase the hemoglobin specific activity. This increase in specific activity may not reflect increased hemoglobin synthesis since, for example, hypoxia may cause a shrinkage of the intracellular pool of nonlabeled iron during preincubation, with a consequent lesser dilution of the radioactive label. The consistently greater relative stimulation of fetal hemoglobin synthesis under conditions of severe hypoxia is evident again.

An attempt was made to determine the time course of the effects of hypoxia on fetal and adult hemoglobin synthesis. Equal portions of the reticulocyte-rich umbilical cord red cells were incubated in four separate Erlenmeyer flasks with $\mathrm{Fe}^{59}$-labeled iron-binding protein as usual, two under 95 per cent $\mathrm{O}_{2}$ and 5 per cent $\mathrm{CO}_{2}$, and two under 95 per cent $\mathrm{N}_{2}$ and 5 per cent $\mathrm{CO}_{2}$. After two hours the incubation was stopped for a pair of flasks, one oxygenated and one hypoxic, while the remaining pair was incubated for four hours as usual. The result of this experiment is shown 

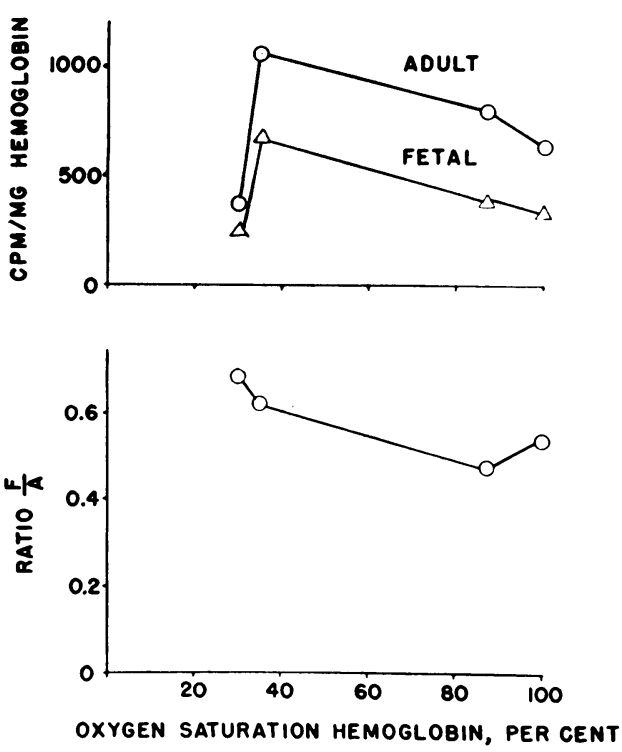

Fig. 2. EFFECT OF VARIOUS DEgReEs OF OXYGEN DEFICIENCY ON THE SYNTHESIS OF ADULT AND FETAL HEMOGLOBIN IN VITRO. The changes in specific activity of the adult and fetal hemoglobins recovered are depicted in the top portion of the figure; the ratio of fetal hemoglobin specific activity to adult hemoglobin specific activity is shown in the bottom portion.

in Figure 3. A significant change in the ratio of hemoglobin synthesized did not occur until the last two hours of the four hour incubation. This was due apparently to a relatively greater decrease in the rate of fetal hemoglobin production in the 95 per cent $\mathrm{O}_{2}$ environment.

Effect of metabolic inhibition. The effect of glucose deficiency, cyanide and methylene blue may be seen in Table II. Glucose deficiency, like oxygen lack, depressed adult hemoglobin synthesis relatively more than fetal hemoglobin synthesis. The addition of $120 \mathrm{mg}$ per $100 \mathrm{ml}$ desoxyglucose to the glucose-deficient medium had no additional effect. Both cyanide and methylene blue almost completely stopped synthesis of both hemoglobins, so that the ratios are of little quantitative significance, but are included to demonstrate that inhibition of these types did not favor fetal hemoglobin synthesis.

Effect of amino acid deficiencies. The effect of various amino acid deficiencies may be seen in Table III. Fetal and adult human hemoglobin differ in valine, isoleucine, and histidine content.
Fetal hemoglobin has less valine than adult hemoglobin has (9.5 vs $11.2 \mathrm{~g}$ per $100 \mathrm{~g}$ ), the missing valine being replaced almost mole for mole by isoleucine $(1.46 \mathrm{~g}$ per $100 \mathrm{ml})$, which the main component of adult hemoglobin lacks entirely (4, 10). Fetal hemoglobin also has less histidine (7.7 vs $8.4 \mathrm{~g}$ histidine per $100 \mathrm{~g}$ ) (10). Thus, the effects of deficiencies of these three amino acids were studied. From Table III we see that isoleucine, and histidine deficiencies in the incubation medium had no effect on Fe uptake. Valine deficiency in two experiments seemed to increase relative fetal hemoglobin synthesis and although the results here are not significant, they suggest further study.
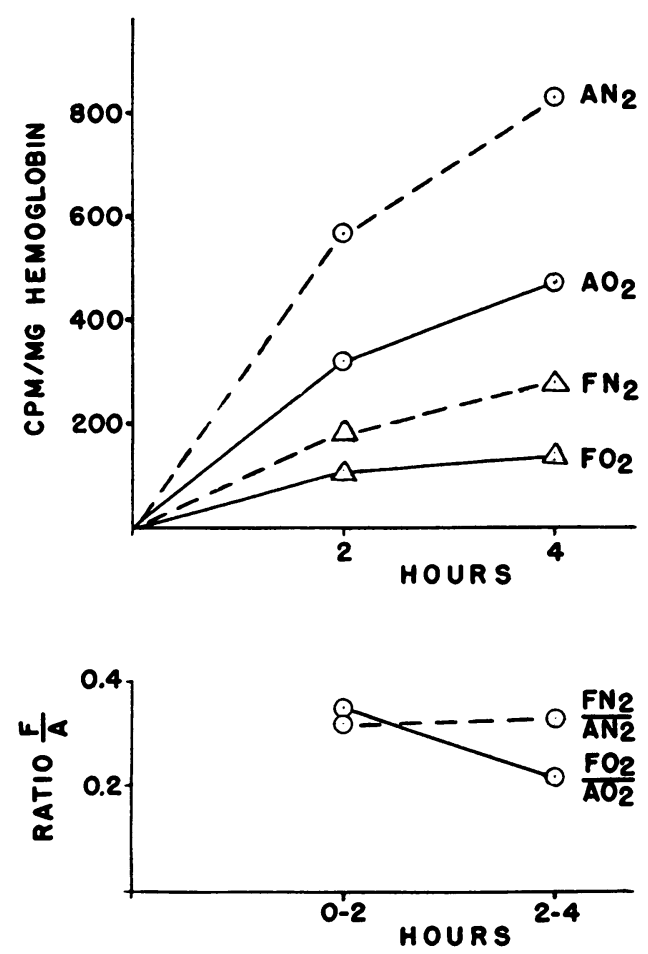

Fig. 3. Time course of Synthesis of FEtal AND ADULT HEMOGLOBIN BY UMBILICAL CORD RETICULOCYTES UNDER NITROGEN AND UNDER OXYGEN IN VITRO, The rate of synthesis of both $\mathrm{A}$ hemoglobin $(\odot)$ and $\mathrm{F}$ hemoglobin $(\triangle)$ diminished during the second two-hour period of incubation both under oxygen ( - ) and under nitrogen (---). Diminution in hemoglobin synthesis was greatest in respect to the rate of $F$ hemoglobin synthesis under oxygen. In the lower diagram the ratio of fetal to adult hemoglobin synthesized is compared for the first two-hour period with the ratio for the second two-hour period. 
TABLE II

Effect of glucose deficiency, cyanide, and methylene blue on the relative synthesis of adult and fetal hemoglobin by cord blood reticulocytes in vitro

\begin{tabular}{|c|c|c|c|c|c|c|c|c|}
\hline Label & $\begin{array}{l}\text { Reticulo- } \\
\text { cytes }\end{array}$ & $\mathrm{F}_{I I} *$ & & Addition to flask & F & $\mathbf{A}$ & $\begin{array}{l}\text { Ratio } \\
\text { F/A }\end{array}$ & $\begin{array}{l}\text { Per cent change } \\
\text { from control ra- } \\
\text { tio F/A in in- } \\
\text { hibited flask }\end{array}$ \\
\hline & $\%$ & $\%$ & \multicolumn{6}{|c|}{$c p m / m g H b$} \\
\hline $\mathrm{Fe}^{59}$ & 2.3 & 56 & $\begin{array}{l}\text { Control } \\
\text { Inhibited }\end{array}$ & $\begin{array}{c}\text { Glucose } \\
0\end{array}$ & $\begin{array}{l}137 \\
149 \\
138\end{array}$ & $\begin{array}{l}332 \\
319 \\
290\end{array}$ & $\begin{array}{l}0.41 \\
0.47 \\
0.48\end{array}$ & $\begin{array}{l}15 \\
17\end{array}$ \\
\hline$C^{14}$-leucine & 4.5 & 66 & $\begin{array}{l}\text { Control } \\
\text { Inhibited } \\
\text { Inhibited } \\
\text { Inhibited }\end{array}$ & $\begin{array}{l}\text { Glucose } \\
120 \mathrm{mg} \% \text { desoxy- } \\
\text { glucose } \\
\text { Glucose }+ \\
10^{-2} \mathrm{NaCN} \\
\text { Glucose }+ \\
0.002 \% \text { methylene } \\
\text { blue }\end{array}$ & $\begin{array}{r}603 \\
577 \\
646 \\
645 \\
31 \\
24 \\
28 \\
35\end{array}$ & $\begin{array}{r}1,154 \\
1,160 \\
1,154 \\
1,157 \\
91 \\
91 \\
86 \\
109\end{array}$ & $\begin{array}{l}0.52 \\
0.50 \\
0.56 \\
0.56 \\
0.34 \\
0.26 \\
0.33 \\
0.32\end{array}$ & $\begin{array}{r}8 \\
12 \\
-33 \\
-49 \\
-35 \\
-37\end{array}$ \\
\hline
\end{tabular}

* Main component of fetal hemoglobin determined by chromatography.

\section{DISCUSSION}

Hypoxia uniformly favored the production of fetal hemoglobin compared with adult hemoglobin as seen in Table I and Figure 1. In the presentation of these experiments, we have emphasized the ratio of fetal and adult hemoglobin synthesized rather than their individual rates of synthesis. Since both fetal and adult hemoglobin-synthesizing mechanisms apparently share the same pool, this ratio of the specific activity of two hemoglobins, made in the same cell, is presumably not influenced by changes in the intracellular pool size. Although, as mentioned earlier, both $\mathrm{F}$ and $\mathrm{A}$ hemoglobin are probably synthesized within the same cells, there is some evidence that the proportions of adult and fetal hemoglobins may vary somewhat from one cell to another (11). Thus it is possible that the adult and fetal synthesizing mechanisms are present in young red cells in varying amounts. This should not, however, invalidate the measurement of the ratio of hemoglobins synthesized.

The generally accepted explanation of the function of fetal hemoglobin is that it represents a specific adaptation for life in utero, by providing the fetus with red cells with a greater affinity for oxygen (12). While human fetal red cells do indeed have a greater affinity for oxygen at a given $\mathrm{Po}_{2}$ than do adult red cells (i.e., the oxygen dissociation curve is "shifted to the left") (12, 13 ), the curve for hemolyzed fetal red cells is actually to the right of that of a hemolysate of maternal red cells, and when both hemoglobins have been dialyzed their oxygen dissociation curves become identical (14). Furthermore, whereas fetal red cells may lose their heightened oxygen affinity within a month after birth (12), fetal hemoglobin

TABLE III

Effect of deficiency of various amino acids on rates of adult and fetal hemoblogin synthesis in vitro by cord blood reticulocytes, using $F^{59}$ incorporation into hemoglobin

\begin{tabular}{|c|c|c|c|c|c|c|c|c|c|c|c|c|c|c|c|c|}
\hline \multirow[b]{2}{*}{$\begin{array}{l}\text { Reticulo- } \\
\text { cytes }\end{array}$} & \multirow[b]{2}{*}{$F_{I I} *$} & \multicolumn{3}{|c|}{ Complete } & \multicolumn{3}{|c|}{ - Isoleucine } & \multirow{2}{*}{$\begin{array}{l}\text { Per cent change } \\
\frac{F_{I} / A_{I}-F_{c} / A_{c}}{F_{c} / A_{c}}\end{array}$} & \multicolumn{3}{|c|}{$\begin{array}{c}\text { Deficient } \\
\text { - Histidine }\end{array}$} & \multirow{2}{*}{$\begin{array}{l}\text { Per cent change } \\
\frac{F_{\mathrm{I}} / \mathrm{A}_{\mathrm{I}}-\mathrm{F}_{\mathrm{c}} / \mathrm{A}_{\mathbf{c}}}{\mathrm{F}_{\mathrm{c}} / \mathrm{A}_{\mathbf{c}}}\end{array}$} & \multicolumn{3}{|c|}{-Valine } & \multirow{2}{*}{$\begin{array}{l}\text { Per cent change } \\
\frac{F_{I} / A_{I}-F_{c} / A_{c}}{F_{c} / A_{c}}\end{array}$} \\
\hline & & $F_{c}$ & $A_{c}$ & Ratio & $F_{1}$ & $A_{I}$ & $\begin{array}{r}\text { Ratio } \\
\mathbf{F}_{\text {I }} / \mathbf{A I}_{\mathbf{I}}\end{array}$ & & $F_{I}$ & Ar & $\begin{array}{r}\text { Ratio } \\
\text { FI }_{I} / A_{I}\end{array}$ & & $F_{\mathbf{I}}$ & AI & $\begin{array}{r}\text { Ratio } \\
\text { FI/AI }\end{array}$ & \\
\hline$\%$ & $\%$ & \multicolumn{2}{|c|}{$c p m / m g H b$} & \multicolumn{4}{|c|}{$c p m / m g H b$} & \multicolumn{4}{|c|}{$c p m / m g H b$} & \multicolumn{4}{|c|}{$c p m / m g H b$} & \\
\hline $\begin{array}{l}5.6 \\
4.3 \\
4.6 \\
2.4\end{array}$ & $\begin{array}{l}46 \\
61 \\
74 \\
66\end{array}$ & $\begin{array}{r}147 \\
196 \\
120 \\
61\end{array}$ & $\begin{array}{l}369 \\
410 \\
346 \\
129\end{array}$ & $\begin{array}{l}0.40 \\
0.48 \\
0.35 \\
0.47\end{array}$ & $\begin{array}{l}144 \\
182\end{array}$ & $\begin{array}{l}380 \\
375\end{array}$ & $\begin{array}{l}0.38 \\
0.49\end{array}$ & $\begin{array}{r}-5 \\
2\end{array}$ & $\begin{array}{r}115 \\
59\end{array}$ & $\begin{array}{l}340 \\
131\end{array}$ & $\begin{array}{l}0.34 \\
0.45\end{array}$ & $\begin{array}{l}-3 \\
-4\end{array}$ & $\begin{array}{r}105 \\
146 \\
110 \\
46 \\
40\end{array}$ & $\begin{array}{r}233 \\
300 \\
321 \\
80 \\
82\end{array}$ & $\begin{array}{l}0.45 \\
0.49 \\
0.34 \\
0.58 \\
0.49\end{array}$ & $\begin{array}{r}13 \\
2 \\
-3 \\
23 \\
4\end{array}$ \\
\hline
\end{tabular}

* Main component of fetal hemoglobin determined by chromatography. 
disappears at a more leisurely pace (15). Thus, the concept that the primary function of fetal hemoglobin is for its specific properties in oxygen transport is difficult to defend. However, the possibility that the increased affinity of fetal hemoglobin for oxygen within the red cell is due to a property of fetal hemoglobin not evident in solution, has not been ruled out.

An alternate explanation is suggested by the consideration that the organism producing fetal hemoglobin has many other demands for oxygen, energy-yielding metabolites, and essential amino acids. Hence, a protein with a smaller content of certain essential amino acids and requiring less energy to produce might possess an advantage for the fetus.

The importance of hypoxia, glucose deficiency, or possibly valine deficiency in directly regulating fetal hemoglobin production can only be suggested, not determined, by these in vitro experiments. At birth the blood flowing to the fetus from the placenta, before respiration, has usually been found to be about 50 per cent saturated with oxygen (16). Certainly one might expect this degree of saturation to be further reduced in the tissue capillaries. The fetus seems to be well supplied with glucose, although the possibility of local deficiency cannot be excluded. Valine deficiency is evidently not severe in the fetus (17) but local tissue deficiency may exist. Although the changes in synthesis rates reported here are small, it must be remembered that the incubation period was carried out during only a small segment of the total time of hemoglobin synthesis by the maturing red cell. Therefore, an effect of one or all of these deficiencies in the direct regulation of fetal hemoglobin production seems possible.

The observation that time of birth during fetal life has no discernible effect on the rate of replacement of fetal hemoglobin $(18,19)$ is against any direct mediation of oxygen on the regulation of fetal hemoglobin production. Since rapid growth rate, rather than intrauterine existence, might condition local glucose or valine deficiency, this same observation is less opposed to the idea of these substances as regulators.

Regardless of the role of these deficiencies in the regulation of fetal hemoglobin production in the normal infant, it is possible that fetal hemoglobin is an adaptation to these deficiencies. This possibility provides impetus for the investigation of defects of energy or amino acid metabolism in congenital anemias of adults characterized by large amounts of fetal hemoglobn, such as thalassemia.

\section{SUMMARY}

1. Reticulocyte-rich suspensions of umbilical cord blood red cells were incubated in vitro with $\mathrm{Fe}^{59}$-iron-binding protein, or $\mathrm{C}^{14}$-leucine, and the amounts of $\mathrm{Fe}^{59}$-labeled or $\mathrm{C}^{14}$-labeled fetal or adult hemoglobin newly synthesized were measured separately.

2. Conditions of hypoxia, or glucose deficiency, favored the formation of fetal hemoglobin as compared to adult hemoglobin.

3. It is possible that fetal hemoglobin may be an adaptation to the fetal environment in which oxygen and glucose are at a premium.

\section{ADDENDUM}

Since this paper was submitted for publication a communication presenting similar observations has appeared [Thomas, E. D., Lochte, H. L., Jr., Greenough, W. B., II., and Wales, M. In itro synthesis of foetal and adult haemoglobin in foetal haematopoietic tissues. Nature (Lond.) 1960, 185, 396]. This finding of an increase in the proportion of hemoglobin $F$ synthesis relative to hemoglobin A with anoxia, is in agreement with our results despite differences in tissue used, length of incubation, radioactive label, and method of isolation of the hemoglobins.

\section{REFERENCES}

1. White, J. C., and Beaven, G. H. Foetal haemoglobin. Brit. Med. Bull. 1959, 15, 33.

2. Itano, H. A. The human hemoglobins: Their properties and genetic control. Advanc. Protein Chem. 1957, 12, 215.

3. Inman, J. K. Preparation of crystalline beta ${ }_{1}$-metal combining protein in Proceedings of the Tenth Conference on the Plasma Proteins and Cellular Elements of the Blood, sponsored by the Protein Foundation, Inc. Cambridge, Mass., 1956, p. 46.

4. Allen, D. W., Schroeder, W. A., and Balog, J. Observations on the chromatographic heterogeneity of normal adult and fetal human hemoglobin: A study of the effects of crystallization and chromatography on the heterogeneity and isoleucine content. J. Amer. chem. Soc. 1958, 80, 1628.

5. Stein, W. H., and Moore, S. The free amino acids of human blood plasma. J. biol. Chem. 1954, 211, 915. 
6. Allen, D. W., and Jandl, J. H. Kinetics of intracellular iron in rabbit reticulocytes. Blood 1960, 15, 71 .

7. Shemin, D. Biosynthesis of protoporphyrin in Methods in Enzymology, S. P. Colowick and N. O. Kaplan, Eds. New York, Academic Press Inc., 1957, vol. 4, p. 643.

8. Thomas, E. D. In vitro studies of erythropoiesis. II. The effect of anoxia on heme synthesis. Blood $1955,10,612$.

9. Gordy, E., and Drabkin, D. L. Spectrophotometric studies. XVI. Determination of the oxygen saturation of blood by a simplified technique, applicable to standard equipment. J. biol. Chem. 1957, 227, 285.

10. Stein, W. H. Observations of the amino acid composition of human hemoglobins in Conference on Hemoglobin. Washington, National Academy of Sciences, National Research Council, 1958, p. 220.

11. Singer, K., and Fisher, B. Studies on abnormal hemoglobins. V. The distribution of type S (sickle cell) hemoglobin and Type $F$ (alkali resistant) hemoglobin within the red cell population in sickle cell anemia. Blood 1952, 7, 1216.

12. Darling, R. C., Smith, C. A., Asmussen, E., and
Cohen, F. M. Some properties of human fetal and maternal blood. J. clin. Invest. 1941, 20, 739.

13. McCarthy, E. F. The oxygen affinity of human maternal and foetal haemoglobin. J. Physiol. (Lond.) 1943-44, $102,55$.

14. Allen, D. W., Wyman, J., Jr., and Smith, C. A. The oxygen equilibrium of fetal and adult human hemoglobin. J. biol. Chem. 1953, 203, 81.

15. Jonxis, J. H. P. Foetal haemoglobin and Rh antagonisms in Haemoglobin-Barcroft Symposium. New York, Interscience Publishers, Inc., 1949, p. 261.

16. Smith, C. A. The Physiology of the Newborn Infant, 2nd ed. Springfield, Ill., Charles C Thomas, 1951.

17. Allen, D. W. The concentrative ability of normal adult, fetal, and thalassemic human reticulocytes for different amino acids. In preparation.

18. Walker, J., and Turnbull, E. P. N. Haemoglobin and red cells in the human foetus. III. Foetal and adult haemoglobin. Arch. Dis. Childh. 1955, 30, 111.

19. Cook, C. D., Brodie, H. R., and Allen, D. W. Measurement of fetal hemoglobin in newborn infants. Pediatrics 1957, 20, 272. 